\title{
Mądrość, kontemplacja, syndereza i sumienie w etyce Tomasza $\mathrm{z}$ Akwinu
}

\author{
Michał Zembrzuski \\ (Uniwersytet Kardynała Stefana Wyszyńskiego w Warszawie, \\ Wydział Filozofii Chrześcijańskiej)
}

\section{Wprowadzenie}

Mądrość, kontemplacja i sumienie podane zostały przez Mieczysława Gogacza jako zasady etyki tomistycznej, nazwanej przez niego „etyką chronienia osób”'. Choć ta propozycja etyki związana jest ściśle z pewnymi zasadniczymi założeniami metafizyki tomizmu konsekwentnego, opartego na dostrzeżeniu w myśli Tomasza egzystencjalnych twierdzeń opisujących byt istniejący, to należy domniemywać, że wskazane pryncypia przynależą do kluczowych norm etyki samego Akwinaty.

Etyce Tomasza z Akwinu poświęcono oczywiście wiele studiów i w związku z tym nie należy się silić na prezentowanie różnych ujęć czy interpretacji, ponieważ z góry są skazane na zarzut fragmentaryczności. Należy mimo wszystko zwrócić uwagę na to, że odczytanie przez Tomasza w naturze ludzkiej dwóch zasad poznawania: intelektu możnościowego i czynnego, które organizują specyficznie ludzki kontakt z rzeczywistością, pozwala na wskazanie, że działania tych władz, a w konsekwencji udoskonalenia, umożliwiają lepsze działanie człowieka

Zob. M. Gogacz, Wprowadzenie do etyki chronienia osób, Warszawa 1998, s. 11-14; tenże, Ku etyce chronienia osób. Wokół podstaw etyki, Warszawa 1991, s. 172-177; tenże, Sumienie, kontemplacja, mądrość (z problematyki podstaw etyki), „Studia Philosophiae Christianae” 1989, nr 25, z. 2, s. 65-71. 
w ramach osiągania celu, a być może po prostu zapewniają dobre działania, to znaczy właściwe dla człowieka jako natury rozumnej. Dzięki temu normy moralności powinny być uzasadniane $\mathrm{w}$ świetle tych dwóch władz poznawczych. Normatywność zasad postępowania moralnego jest $\mathrm{w}$ ten sposób osadzona na naturze człowieka i w niej ma uzasadnienie. Mądrość jest dla Tomasza sprawnością (teoretyczną) intelektu możnościowego, podobnie jak syndereza (sprawność praktyczna), natomiast kontemplacja i sumienie stanowią akty intelektu możnościowego.

W artykule przyjrzymy się tym czterem zasadom etyki, odczytując ich znaczenie $\mathrm{w}$ tekstach Tomasza $\mathrm{z}$ Akwinu, a także powiążemy je $\mathrm{z}$ dwoma wyróżnionymi za Arystotelesem intelektami: możnościowym i czynnym. Artykuł będzie więc próbą zweryfikowania, na ile teksty Tomasza pozwalają na wprowadzenie sugerowanych przez twórcę etyki chronienia osób zasad postępowania moralnego. Z pewnością, gdy mowa jest o sprawnościach intelektu jako warunkujących postępowanie, należałoby szczególne miejsce poświęcić roztropności. Ta wyjątkowa sprawność jednak o wiele częściej stanowi przedmiot zainteresowania badaczy myśli etycznej Akwinaty i zyskała dogłębne opracowania w kontekście czynności poznawczych ${ }^{2}$.

Treść artykułu została uporządkowana tematycznie. Najpierw omówiona zostanie mądrość i jej znaczenie w etyce Akwinaty, następnie kontemplacja, a na końcu syndereza i sumienie. Mądrości poświęcono najwięcej miejsca ze względu na jej uprzywilejowane miejsce w całej twórczości Tomasza. Zastosowanie zasad mądrości do praktycznych działań jest samorzutne. Bardzo łatwo można odnaleźć pryncypia postępowania etycznego, które wynikają z pozycjonowania mądrości. Z pewnością podobne aplikowanie wypowiedzi Tomasza powinno dotyczyć także pozostałych działań poznawczych, jednak nie zostało zrealizowane w niniejszym artykule.

Zob. W. Galewicz, Wstęp tłumacza, w: Tomasz z Akwinu, Traktat o roztropności, Kęty 2011, s. 7-39. Por. M. Zembrzuski, Sprawności intelektu wyrazem wewnętrznej kultury osoby w kontekście myśli Tomasza z Akwinu, „Studia Philosophica Wratislaviensia” 2016, t. 11, nr 3, s. 85-102; tenże, Wychowanie jako uprawa intelektu. Problematyka sprawności intelektu w ujęciu wybranych tomistów polskich (J. Woroniecki, S. Swieżawski, M. Gogacz), w: Myśl pedagogiczna neoscholastyki i neotomizmu, red. A. Murzyn, M. Krasnodębski, Warszawa 2014, s. 179-202. 


\section{Rola mądrości w etyce Akwinaty}

Przez „mądrość” Akwinata rozumiał „wiedzę” (w znaczeniu „skutku poznania”, a nie „sprawności dla sprawności”) przedmiotowo zorientowaną na najwyższe przyczyny (lub najwyższą przyczynę). Była to dla niego jednocześnie pewna dyspozycja do osądzania i porządkowania wszystkiego według ostatecznych zasad. Jak pisze Tobias Hoffmann, można to rozumieć dwojako - zarówno komparatywnie, jak i absolutnie ${ }^{3}$. Komparatywne rozumienie związane jest $\mathrm{z}$ tym, że „człowiekiem mądrym” może być nazywany ten, kto zna się na rzeczach wyższego rzędu, a dzięki takiej wiedzy, może oceniać rzeczy niższego rzędu - architekt jest mądrzejszy niż murarz i dekarz. Absolutne rozumienie wskazuje na człowieka mądrego, który będzie posiadał wiedzę o najwyższej przyczynie (którą jest Bóg) i będzie oceniał na tej podstawie całą niższą rzeczywistość względem tej jedynej. Akwinata, jak się wydaje, zastosował to absolutne rozumienie mądrości do trzech poziomów poznania Boga, tym samym wyróżnił trzy jej odmiany, wypowiadając się na ten temat $\mathrm{w}$ różnych swoich dziełach: (1) mądrość wyznaczona przez naturalne poznanie Boga (na tyle, na ile jest ono możliwe) w ramach tego, co bywa obecnie nazywane "teologią filozoficzną", a wcześniej było nazywane po prostu „metafizyką"; (2) mądrość utożsamiona z teologią jako sacra doctrina, jako wiedzą o Bogu opartą na Objawieniu5; (3) mądrość jako dar Ducha Św., dzięki któremu człowiek może oceniać rzeczywistość zgodnie z zasadami Boskimi ${ }^{6}$. Trzeba dodatkowo pamiętać, że Akwinata mądrość wiąże ze szczęściem (rozumianym zarówno jako felicitas, jak i beatitudo), przez co okazuje się ona najważniejszą spośród teoretycznych sprawności intelektualnych, najmocniej oddziałujących na etyczne postępowanie ${ }^{7}$. Konsekwencją tego będzie to, że życie

Zob. T. Hoffmann, The intellectual virtues, w: The Oxford Handbook to Aquinas, ed. by B. Davies, E. Stump, Oxford University Press 2012, s. 330.

4 Zob. SCG I, c. 2; InMET I, 1. 1, n. 35. W artykule stosuję następujące skróty odnoszące się do tekstów Akwinaty: SENT - Commentum in libros sententiarum magistri Petri Lombardi; SCG Liber de veritate catholicae fidei contra errores infidelium seu Summa contra gentiles; ST - Summa theologiae; QDV - Quaestiones disputatae de veritate; InMET - Sententia libri Metaphysicae; InPA - Sententia libri Posteriorum Analyticorum; InNE - Sententia libri Ethicorum; InCOR - Super II Epistolam B. Pauli ad Corinthios lectura; InDC - Sententia libri De caelo et mundo. Korzystam $\mathrm{z}$ tekstów łacińskich znajdujących sie na stronach internetowych: www.corpusthomisticum.org. Zob. ST I, q. 1, a. 6, co.

Zob. ST II-II, q. 45, a. 1-6.

Zob. ST I-II, q. 4, a. 8, co. 
kontemplacyjne, jako wyraz działań człowieka będącego osobą, będzie wyższe i ważniejsze niż życie praktyczne.

Ujęcie komparatywne i absolutne mądrości można wyrazić jeszcze inaczej: 1) mądrość rozważa nie tylko to, co przynależy do jakiegoś najwyższego, ale szczegółowego obszaru rzeczy intelektualnie poznawalnych (fizyka ostatecznie rozważa najważniejsze zasady bytów podlegających zmianom a matematyka najwyższe zasady rzeczywistości ilościowej), lecz także to, co wprost stanowi obszar najwyższych przyczyn i zasad bytu (należą do nich między innymi istota i istnienie, akt i możność, forma i materia w bycie, substancja i powiązanie jej z przypadłościami); 2) ponieważ mądrość dotyczy tego, co jest najważniejsze w całej rzeczywistości, to może funkcjonować jako wiedza o charakterze architektonicznym - może rozważać różne rodzaje nauk, koordynować relacje między nimi, a także bronić się wedle swoich zasad przed tą wiedzą, która mogłaby mądrość niszczyć. Akwinata o tej funkcji jednoczącej mówi, że mądrość działa wówczas dzięki rozumieniu (intellectus) ${ }^{8}$; 3) ze względu na pierwszeństwo wśród różnych rodzajów wiedzy, mądrość wedle Tomasza pozostaje czymś jednym (sapientia non sit nisi una $)^{9}$. Mądrość pozostaje więc wiedzą uzyskaną przez intelekt, wiedzą najwyższą, bo odnoszącą się do tego, co najwyższe i ostateczne w rzeczywistości.

Przejdźmy teraz do ukazania wartości mądrości. Można tego dokonać przez wskazanie, jak Tomasz zinterpretował pochodzące od Arystotelesa określenie mądrości ${ }^{10}$. Sformułowania te odnaleźć można w jego Komentarzu do „Metafizy$k i$ ”Stagiryty (nieco inaczej będzie je prezentował w Komentarzu do „Etyki”"1). Tomasz interpretuje wypowiedzi Arystotelesa dwojako - jako wskazówki dotyczące samej mądrości, a także wypowiedzi określające samą metafizykę jako mądrość. Co ciekawe, w interpretacji Arystotelesa w żaden sposób nie aplikuje rozważań o mądrości w znaczeniu teologicznym, uznając za własne wypowiedzi Filozofa. Zdaniem Tomasza mądrość można opisać za pomocą sześciu punktów, które stanowią jej swoiste warunki albo też wyznaczniki: 1) maksymalizm poznawczy ${ }^{12}$; 2) poznanie tego, co trudne dla poznania (przedmiotem jest to, co intelektualne,

InPA II, 1. 20, n. 15: „Sapientia, ut ibidem dicitur, comprehendit in se scientiam et intellectum, est enim quaedam scientia et caput scientiarum".

9 ST I-II, q. 57 a. 2 co. „Ad id vero quod est ultimum in hoc vel in illo genere cognoscibilium, perficit intellectum scientia. Et ideo secundum diversa genera scibilium, sunt diversi habitus scientiarum, cum tamen sapientia non sit nisi una”.

10 Zob. Arystoteles, Metafizyka I, 2 (982a1-983a23), tłum. K. Leśniak, Warszawa 2009, s. 24-27.

11 Zob. InNE VI, 1. 5, n. 1-9.

12 InMET I, 1. 2, n. 1. 
a nie to, co zmysłowe $)^{13}$; 3) pewność wiedzy ${ }^{14}$; 4) znajomość przyczyn, co wyjaśnia każdą rzecz ${ }^{15}$; 5) wiedza, która jest wybierana ze względu na nią samą ${ }^{16}$;6) wiedza godniejsza niż wiedza służebna ${ }^{17}$.

Wszystkie te określenia odpowiadają mądrości jako pewnemu rodzajowi wiedzy, która pozwala na wyciąganie wniosków z poznania pierwszych zasad. Ma ona naturę teoretyczną, co wcale nie jest jakąś szkodą czy uszczerbkiem, ale pokazuje, jak bardzo zdolność poznawacza człowieka może wznieść się do oglądania tego, co jest możliwie najwyższe do oglądania. Ale i tak najważniejsza dla tego teoretycznego obrazu jest wskazówka mówiąca o tym, że mądrość pozostaje najważniejszą spośród sprawności intelektualnych człowieka (zarówno teoretycznych i praktycznych) ${ }^{18}$. W sposób bezwzględny (simpliciter) sprawności intelektualne są najwyższymi dyspozycjami człowieka ze względu na przedmiot ${ }^{19}$. Oczywiście, wątpliwości mogą budzić zastrzeżenia wynikające z przeciwstawienia mądrości i roztropności. Jednak to właśnie ściśle określony przedmiot mądrości, która obraca się wokół najwyższych przyczyn (de altissimis), pozwala na osądzanie przyczyn niższych, a nawet zarządzanie nimi, by doprowadzić do stanu mądrości. Akwinata, wyrażając wyższość mądrości nad innymi sprawnościami intelektualnymi, dopuszczał, że inne sprawności mogą w pewien sposób uzyskać poziom usprawnień, który odpowiadałby samej mądrości. Oczywiście, takie postawienie sprawy nie było łatwe, ze względu na przypadek różnych rodzajów wiedzy, które z samej definicji dotyczą przyczyn w pewnym obszarze, a mądrość jest przecież jedna. Kłopotem, przed jakim stał Tomasz, było to, czy można faktycznie pokazać ścisłe różnice między mądrością, sprawnością zasad i wiedzą ${ }^{20}$. Przecież można uznać, że wyrażenia stanowiące ich nazwy są synonimiczne. Mądrość przecież też jest pewnego rodzaju wiedzą, choć ma w sobie coś, co ją wynosi ponad wszystkie inne wiedze, a także jest pewną sprawnością zasad. Różnice między nimi, jak sądzi Tomasz, bardziej wynikają z porządku zależności, aniżeli z różnych przedmiotów materialnych: wiedza zależy od sprawności zasad, a obydwie

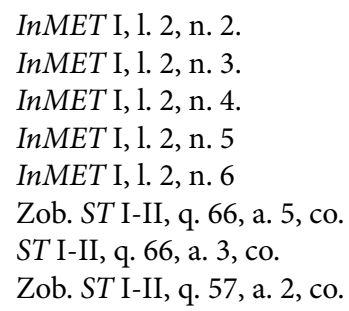


od mądrości, „która obejmuje pojmowanie i wiedzę, gdyż osądza tak wnioski wiedzy, jak i jej zasady"21.

Jeśli zaś chodzi o wyższość mądrości nad roztropnością, to Tomasz podkreśla, że poza przedmiotem można mówić także o służebnej roli roztropności względem mądrości - „decyduje o rzeczach służących mądrości, mianowicie o tym, jak ludzie powinni nabywać mądrości” ${ }^{22}$. Dodatkowo należy określić mądrość przez kres, do którego zmierza, a jest nim szczęście każdego człowieka, roztropność obraca się wyłącznie wokół środków prowadzących do niego. Oczywiście, samo poznanie celu i rozważanie go wcale nie oznacza natychmiastowego posiadania tego przedmiotu. Mądrość, w której usprawnia się człowiek, jest zapoczątkowaniem pełnej mądrości uzyskanej w osiągnięciu kresu ludzkiego życia. W ten sposób mądrość przewyższa roztropność tym, że jest „cząstkowym zapoczątkowaniem" szczęścia ${ }^{23}$. Nieposiadanie doskonałej mądrości ściśle wiąże się z pewnością, jaką człowiek mógłby (choć nie może) uzyskać w ramach poznania najwyższej przyczyny. W tym aspekcie mogłoby się wydawać, że roztropność posiada większą pewność, gdyż obraca się wokół tego, co stanowi przedmiot ludzkiej wiedzy i mieści się w zasięgu jego zdolności poznawczych. $Z$ różnych rodzajów wiedzy może przecież wynikać roztropne działanie, które może być skuteczniejsze od działania wynikającego z mądrości. Tomasz odpowiada na ten zarzut jednoznacznie, odwołując się do różnych wypowiedzi Arystotelesa na temat niepełności poznania najdoskonalszych przedmiotów: 1) „W odniesieniu do bytów niebieskich wielką wartość ma nawet poznanie niepewne i niedoskonałe"; 2) „milszą rzeczą jest dowiedzieć się choćby niewiele o rzeczach wznioślejszych, niż wiedzieć wiele o rzeczach mniej ważnych”; 3) „choć zatem mądrość, której dziełem jest poznanie Boga, zwłaszcza w tym życiu nie może przysługiwać człowiekowi w stopniu tak doskonałym, by stanowiła jakby jego własność - w ten bowiem sposób przysługuje tylko Bogu (...) - to jednak nawet tę skromną wiedzę,

${ }^{21}$ ST I-II, q. 57, a. 2, ad 2. Cyt. za: Tomasz z Akwinu, Traktat o cnotach, tłum. W. Galewicz, Kęty 2006, s. 141.

22 ST I-II, q 66, a. 5, ad 1. Bardzo interesujący w tym względzie jest zarzut $\mathrm{z}$ artykułu podejmującego problem wyjątkowości mądrości. Arystoteles sugerował, że to w ramach polityki roztropność wskazuje na to, jakie nauki w systemie edukacyjnym powinny być uprawiane. Tomasz odwraca ten porządek pokazując, że polityka służy mądrości: „prowadzi do niej, gotując jej drogę, tak jak odźwierny wprowadza króla”. ST I-II, q. 66, a. 5, ad 1. Por. M. Gogacz, Mądrość buduje państwo, Niepokalanów 1993, s. 5-9.

23 Zob. ST I-II, q. 66, a. 5, ad 2. 
którą dzięki mądrości możemy uzyskać o Bogu, trzeba przenosić nad wszelką inną" 24 .

Tomasz rozważa także to, czy intelekt (rozumienie) zasad (intellectus principiorum) albo też sprawność, która może wykształcić się w jego ramach, nie stanowi większej umiejętności niż mądrość. Odpowiedź na tę wątpliwość jest dość zaskakująca, gdyż Tomasz mówi, że błędne byłoby rozumienie mądrości, gdyby widziałoby się w niej wyłącznie zdolność do poznania skutków wynikających z najwyższych zasad. Mądrość raczej dotyczy zarówno poznania zasad niedowodliwych, rozumienia podstawowych pojęć i terminów, których używa się we wnioskowaniach, jak i pozwala na ich ocenę oraz obronę przed tymi, którzy mogliby je negować. Mądrość ponownie jest rozumiana w kontekście metafizyki jako rozumienie podstawowych ujęć rzeczywistości, które zawsze sprowadzają się do rozumienia bytu i składowych jego części: „poznanie pojęcia bytu (cognoscere enim rationem entis) i niebytu, całości i części, i innych pojęć wiążących się z bytem, które jako terminy wchodzą w skład niedających się udowodnić zasad, jest zadaniem mądrości, ponieważ powszechny byt jest właściwym skutkiem najwyższej przyczyny, czyli Boga"25. Mądrość jest zatem najszerszą spośród teoretycznych sprawności intelektu możnościowego, ale także i najdalej sięgającą, a także rozporządza sprawnościami praktycznymi. W kontekście mądrości widać wyraźnie, że Tomasz podkreślał rolę tego właśnie intelektu, który dzięki sprawnościom (intelekt czynny nie podlega usprawnieniom) jest w stanie doskonale realizować swoje akty.

\section{Praktyczne znaczenie mądrości}

Praktyczne zastosowanie mądrości w etyce można odnaleźć po następujących jej określeniach, które można wyczytać z tekstów Akwinaty. Dotychczasowe wypowiedzi akcentowały wyłącznie poznawczą jej funkcję - była ona widzeniem rzeczywistości w świetle najwyższych, najpierwotniejszych pryncypiów (albo też jednej najwyższej Przyczyny). Akcenty, które pojawią się teraz, stanowią dopo-

24 ST I-II, q. 66, a. 5, ad 3. Cyt. za: Tomasz z Akwinu, Traktat o cnotach, dz. cyt., s. 236.

25 ST I-II, q. 66, a. 5, ad 4. „Cognoscere autem rationem entis et non entis, et totius et partis, et aliorum quae consequuntur ad ens, ex quibus sicut ex terminis constituuntur principia indemonstrabilia, pertinet ad sapientiam, quia ens commune est proprius effectus causae altissimae, scilicet Dei". Cyt. za: Tomasz z Akwinu, Traktat o cnotach, dz. cyt., s. 236. 
wiedzenia wynikające z pierwszego ujęcia, nie są jednak zbędnym dodatkiem, ale zrębem Tomaszowych wypowiedzi mającym kluczowe znaczenie.

1. Sapientia est ordinare et gubernare - określenie mądrości jako działania porządkującego i zarządzającego, wpisanych w zadania i powinności mędrca, pojawiły się jako wyrażony przez Tomasza cel Summy przeciw poganom (który został zresztą w niezwykły sposób zrealizowany ${ }^{26}$ ). Dla Akwinaty to wyrażenie oznacza kluczową charakterystykę mądrości (zresztą i tak pochodzącą z pism Arystotele$\mathrm{sa}^{27}$ ): ,jest zaś rzeczą konieczną, by reguła rządzenia i porządku płynęła z celu, do którego jest przyporządkowane to, czym się rządzi. Wtedy bowiem każdą rzeczą rozporządza się najlepiej, gdy się ją odpowiednio skieruje do celu - gdyż celem każdej rzeczy jest jej dobro”"28. Akwinata nazwie „mędrcem wprost” (simpliciter) człowieka, który rozważa cel wszechświata, który jest zarazem zasadą porządkującą go. Odniesienie do celu nie jest jedynym ordo, jaki może odczytywać ludzki intelekt, a szczególnie intelekt mędrca. Do porządku można także zaliczyć układ zależności (np. wcześniej-później), relacje, a także hierarchiczność związaną z porządkiem zależności partycypacji.

2. Sapientia est consideratio veritatis - określenie mądrości, która rozważa prawdę, pojawiło się również w Summie przeciw poganom w kontekście określenia Stwórcy, który ustala porządek i cel natury następnie odczytywany przez mędrca. Ostatecznym celem wszechświata jest dobro intelektu, a więc prawda ${ }^{29}$. Co interesujące, Akwinata od razu pokazuje, w jaki sposób powiązać mądrość (i filozofię) z prawdą i istnieniem: „Lecz i pierwszą filozofię określa Filozof jako znajomość prawdy - nie jakiejkolwiek prawdy, lecz tej, która jest źródłem wszelkiej prawdy, a mianowicie tej, która odnosi się do pierwszej zasady istnienia wszystkich rzeczy (primum principium essendi omnibus). Stąd też prawda o niej jest zasadą wszelkiej prawdy, tak samo bowiem mają się rzeczy do prawdy, jak do istnienia"30. W Summie teologii Tomasz omawiał teoretyczne sprawności inte-

26 Zob. M. Przanowski, Święty Tomasz z Akwinu o Bogu. Studia teologiczne, Warszawa 2015, s. 2751.

27 Zob. Arystoteles, Metafizyka I, 2 (982 a 17-18), s. 25.

28 SCG I, c. 1: „Omnium autem ordinatorum ad finem, gubernationis et ordinis regulam ex fine sumi necesse est: tunc enim unaquaeque res optime disponitur cum ad suum finem convenienter ordinatur; finis enim est bonum uniuscuiusque". Cyt. za: Tomasz z Akwinu, Summa contra gentiles. Prawda wiary chrześcijańskiej, tłum. Z. Włodek, W. Zega, Poznań 2003, s. 17. Zob. SCG I, c. 1.

30 SCG I, c. 1: „Sed et primam philosophiam philosophus determinat esse scientiam veritatis; non cuiuslibet, sed eius veritatis quae est origo omnis veritatis, scilicet quae pertinet ad primum 
lektu w kontekście doskonalenia w poznawaniu prawdy, co dokonuje się właśnie albo poprzez sprawność zasad i ich rozumienie (habitus principiorum), albo poprzez wiedzę, albo poprzez mądrość. Rozumienie prawdy w tym dziele i w tym kontekście pojawia się już jako warunek osądzania, polegający na sprowadzeniu czegokolwiek do pierwszych przyczyn i zasad ${ }^{31}$.

3. Sapientia est quasi sapida scientia - to określenie genetycznie wyjaśnia mądrość jako „smaczną wiedzę”. Podkreśla w sposób wyjątkowy powiązanie poznania i wiedzy z przyjemnością płynąca z niej. W jednym z fragmentów Akwinata pisze: „To właśnie stanowi sedno mądrości, która jak wiadomo jest jakimś doznawaniem smaku czy rozkoszy w poznawaniu prawdy - w myśl słów «mądrość bowiem nauki jest według imienia swego» (Syr 6, 22)"32. Mądrość więc wiąże się ściśle ze sferą afektywną, z reakcją woli, gdyż przejawia się w doświadczaniu duchowej przyjemności i słodyczy (experiri spirituales delectationes sive dulcedines) ${ }^{33}$ płynącej z poznania pierwszych przyczyn i zasad. W innym fragmencie przez ten zwrot podkreślone zostaje zaspokojenie, jakie przynosi poznanie mądrościowe: „wówczas mamy do czynienia z prawdziwą mądrością, kiedy działanie intelektu jest udoskonalone i dopełnione przez uspokojenie i zadowolenie pragnienia. Stąd nazywa się mądrość jakby smaczną wiedzą"34.

4. Sapientia est virtus quaedam omnium scientiarum - „mądrość jest pełnią możności wszystkich wiedz". Takie określenie mądrości pojawiło się w Tomaszowym Komentarzu do „Etyki nikomachejskiej” Arystotelesa, który pozostaje kompletnym wykładem i wyjaśnieniem etyki Filozofa ${ }^{35}$. Polscy tłumacze fragmentów dotyczących „cnót intelektu” wskazują, że mądrość w tym dziele zostaje potrak-

principium essendi omnibus; unde et sua veritas est omnis veritatis principium; sic enim est dispositio rerum in veritate sicut in esse". Cyt. za: Tomasz z Akwinu, Summa contra gentiles. Prawda wiary chrześcijańskiej, dz. cyt., s. 18.

31 Zob. ST I-II, q. 57, a. 2, co.

32 ST I, q. 43 a. 5 ad 2: „Et haec proprie dicitur sapientia, quasi sapida scientia, secundum illud Eccli. VI, sapientia doctrinae secundum nomen eius est". Cyt. za: Tomasz z Akwinu, Suma teologiczna. O Trójcy przenajświętszej, tłum. P. Bełch, t. 3, Londyn 1978, s. 218.

33 Zob. ST II-II, q. 45 a. 2 arg. 2. W odpowiedzi na ten zarzut, który lokowal mądrość wprost $\mathrm{w}$ woli, Akwinata wskazuje, że określenie to zostało zaczerpnięte ze „sławy, jaką ma w oczach wszystkich ludzi”. Zob. ST II-II, q. 45, a. 2, ad 2.

34 InCOR. II, cap. 13 1. 3: „Quia tunc est vera sapientia, quando operatio intellectus perficitur et consummatur per quietationem et delectationem affectus. Unde sapientia dicitur, quasi sapida scientia".

InNE VI, 1. 5, n. 9. 
towana wyjątkowo ${ }^{36}$. Po pierwsze, mądrość określona jest jako pewien rodzaj kunsztu, czyli pewien rodzaj mistrzostwa ze względu na pewność tego rodzaju wiedzy (pewność wynika ze znajomości zasad). Po drugie, mądrość w ten sposób określona jako pełnia możności jakiejkolwiek rzeczy, wyraża się w osiąganiu tego, co ostateczne i najdoskonalsze. Po trzecie, mądrość jako zdolność poznania tego, co w ramach poznania zasad bytu dochodzi do tego, co najogólniejsze, a tak naprawdę konieczne w rzeczywistości („takie są zasady charakteryzujące byt, o ile jest bytem i których poznanie należy do mądrości” ${ }^{37}$ ). Po czwarte, pełnia możności władz realizowana w mądrości objawia się tym, że „stwierdza prawdę w odniesieniu do samych zasad”, co przekłada się na objaśnianie tego, co mieści się w terminach zasad (całość-część, równe-nierówne, itd). Po piąte, Tomasz pisze o jej znakomitości, która wiąże się z tą charakterystyką: „odróżnia się jednak od wiedzy wziętej w ogólności, z uwagi na znakomitość, która pośród innych wiedz jej przysługuje; jest bowiem pewną pełnią możności wszystkich wiedz"38. Tłumacze podkreślają, że cały problem interpretacyjny tkwi w przełożeniu i interpretacji słowa virtus, które jest zastosowane do mądrości jako ultimum potentiae („pełnia możności”). Jeśli do rozumienia mądrości zastosujemy określenie „kresu możności”, swoistego maksimum, wówczas finalność z tym związana, ukaże mądrość jako urzeczywistnienie wszystkiego, co człowiek czyni, tworzy, w czym się usprawnia. Jednak mądrość nie będzie tylko celem do spełnienia, ale również - jako coś, w czym człowiek się doskonali - będzie tym, co będzie w nim najdoskonalsze. Dobrze oddają to słowa Tomasza z Komentarza do „O niebie” Arystotelesa: „Jeśli ktoś może unieść sto talentów, będzie mógł unieść i dwa, i jeśli może przejść sto stadiów, może przejść i dwa; jednakże pełnię możności (virtus) rzeczy przypisuje się tylko temu, co najdoskonalsze; inaczej mówiąc, pełni możności rzeczy upatruje się w tym, co jest najdoskonalsze z wszystkiego, co ona może. To właśnie czytamy w innym przekładzie tego miejsca "pełnia możności jest tym, co w możności ostateczne», pełnię możności rzeczy bowiem określa się według maksimum tego, co ona może. Ma to także miejsce w wypadku cnót duszy: cnotą człowieka bowiem jest to, dzięki czemu człowiek może spełniać to, co jest najdoskonalszym z zadań człowieka"39.

\footnotetext{
36 Zob. Tomasz z Akwinu, O cnotach rozumu. Komentarz do VI ksiegi „Etyki nikomachejskiej” Arystotelesa, tłum. M. Głowala, J. Kostaś, M. Otlewska, W. Ziółkowski, Wrocław 2010, s. 94-97.

37 InNE VI, 1. 5, n. 7.

38 InNE VI, 1. 5, n. 9. Cyt. za: Tomasz z Akwinu, O cnotach rozumu, dz. cyt., s. 97.

39 InDC I, 1. 25 n. 4. Cyt. za: Tomasz z Akwinu, O cnotach rozumu, dz. cyt., s. 94.
} 
5. Sapientia est donum Spiritus Sancti - mądrość jako dar Ducha świętego wyraża teologiczny kontekst Tomaszowych wypowiedzi, jednak jest on interesujący poznawczo, gdyż jeszcze bardziej poszerza spectrum widzenia mądrości. Dar ten, którego źródłem jest sam Bóg, pozwala na osądzanie wszystkiego wedle prawideł Bożych (per regulas divinas) ${ }^{40}$ bądź wedle prawdy Bożej (secundum veritatem divinam ${ }^{41}$. Zdolność do tego rodzaju aktów sądzenia wynika ze szczególnego pokrewieństwa, które człowiek zyskuje dzięki temu darowi, a także dzięki miłości, która pozwala na zjednoczenie z Bogiem ${ }^{42}$. Dodatkowo Tomasz podkreśla, że ten dar gwarantuje ukierunkowanie życia ludzkiego, przez co nie jest wyłącznie jakiegoś rodzaju wiedzą, ale dyspozycją praktyczną. Poprzez o wiele głębszą bliskość z najwyższym przedmiotem mądrości dar ten nie należy wyłącznie do dziedziny teoretycznej (kontemplacyjnej), ale wywołuje skutki w dziedzinie praktycznej ${ }^{43}$.

6. Sapientia est directiva humanae vitae - określenie mądrości jako kierowniczki życia pojawia się w Summie teologii w miejscu, w którym Akwinata zastanawia się nad relacją bojaźni Bożej do mądrości. W sposób bardzo wyraźny i ostry rysuje różnicę między mądrością filozofów i mądrością wierzących. Jej poznawcza funkcja została opisana w ramach filozoficznego pragnienia poznania najwyższej przyczyny (est cogniscitiva Dei), natomiast funkcja w życiu chrześcijańskim ma postać kierowania zasadami Bożymi (est directiva humanae vitae). Takie odróżnienie pozwala na wskazanie tego, co jest początkiem życia ludzkiego, tzn. co jest zasadą (principium) wyznaczającą odpowiedni kierunek. Choć Tomasz nie pisze o tym, co jest początkiem mądrości jako funkcji poznawczej (można się z łatwością domyślić, że są to zasady bytu), to jednak wskazuje, że początkiem mądrości chrześcijańskiej są ",artykuły wiary; stąd to mówimy, że wiara jest początkiem mądrości” ${ }^{\text {”4 }}$. Ale początek mądrości może również oznaczać „to, od czego zaczyna ona swoje kierownicze działanie"45. Tym początkiem w życiu chrześcijańskim będzie bojaźń Boża (timor) i to zarówno w sensie bojaźni niewolniczej, jak i dziecięcej. Można zastanowić się jednak, co byłoby odpowiednikiem takiego początku w ramach „filozoficznej mądrości”. Musiałby być to początek,

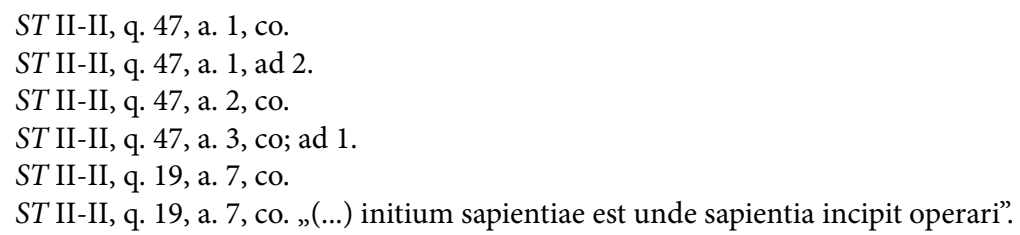


który otwiera, wzmaga i czyni doskonałym (choć nie najdoskonalszym zgodnie z przekonaniem Akwinaty) poznanie najwyższej przyczyny. Z całą pewnością pilność (studiositas) byłaby takim elementem. Tomasz pisze o niej następujące słowa: „Pilność właściwie oznacza mocne zwrócenie umysłu ku czemuś. Umysł zaś zwraca się ku czemuś tylko w celu poznawczym. Stąd w pierwszym rzędzie umysł zwraca się ku poznaniu, w drugim zaś ku temu, ku czemu człowiek kieruje się przez poznanie. Dlatego pilność ma na uwadze przede wszystkim wiedzę, a następnie wszystko, do zdziałania czego potrzebne jest kierownictwo wiedzy"46.

\section{Rola kontemplacji w etyce Akwinaty}

Zagadnienie kontemplacji nieprzypadkowo zostało umieszczone wśród zagadnień etyki Akwinaty. Jest tak dlatego, że autorzy omawiający to zagadnienie podkreślają, że kontemplacja jest zasadą regulującą życie człowieka, a także jest kryterium poprawnego, zgodnego z rzeczywistością, podejmowania decyzji ${ }^{47}$. To kontemplacja wymagając spokoju i pewnego zatrzymania wszelkiej aktywności, wprowadza porządek w uczuciach, a wymagając cnót nabywanych i wlanych, jednocześnie je doskonali. Ponieważ to zagadnienie znakomicie ułatwia dostrzeżenie wagi dystynkcji między intelektem możnościowym i czynnym, należy poświęcić mu kilka chwil uwagi.

Wypowiedzi Tomasza z Akwinu na temat kontemplacji jest bardzo wiele, są różnorodne i domagają się szerszego opracowania. Wśród interpretacji, szczególnie wśród polskich autorów, odnaleźć można przynajmniej dwa sposoby podejścia do tego zagadnienia. Jedno z nich prezentuje Lech Szyndler, a drugie odna-

46 ST II-II, q. 166, a. 1, co. „(...) studium praecipue importat vehementem applicationem mentis ad aliquid. Mens autem non applicatur ad aliquid nisi cognoscendo illud. Unde per prius mens applicatur ad cognitionem, secundario autem applicatur ad ea in quibus homo per cognitionem dirigitur. Et ideo studium per prius respicit cognitionem, et per posterius quaecumque alia ad quae operanda directione cognitionis indigemus". Cyt. za: Tomasz z Akwinu, Suma teologiczna. Umiarkowanie, tłum. S. Bełch, t. 22, Londyn 1963, s. 308.

47 Zob. L. Szyndler, Zagadnienie „verbum cordis” w ujęciu Tomasza z Akwinu, w: Wokót średniowiecznej filozofii języka, t. 1, red. A. Górniak, Warszawa 2002, s. 97. Akwinata pisze o tym w odwrotnym porządku pokazując, że wszelkie działania służą życiu kontemplacyjnemu. W takiej sytuacji, gdybyśmy zapytali, czy dobór działań służących kontemplacji zależy od czegoś, to z pewnością to cel wyznaczałby dobór właściwych i najlepszych środków do niego prowadzących. Zob. SCG III, c. 37. 
leźć można w publikacjach Janusza Idźkowskiego ${ }^{48}$. Co ciekawe, różnice między nimi pokazują, jak bardzo niejasne jest Tomaszowe rozstrzygnięcie dotyczące tego, czy obydwa intelekty biorą udział w kontemplacji. Zdaniem Szyndlera, kontemplacja związana jest ściśle $\mathrm{z}$ intelektem możnościowym i wolą i pojawia się na pewnym etapie opisu poznania intelektualnego. Zdaniem Idźkowskiego kontemplacja jest szerokim zagadnieniem, a ze względu na przedmiot - byty istniejące i Bóg - domaga się korzystania z władz zmysłowych i udziału intelektu czynnego w tej operacji. Różnic pomiędzy ich ujęciami jest bardzo wiele, jednak ciekawe jest to, że stanowią komplementarne ujęcia tego wieloaspektowego zagadnienia. Szyndler na przykład akcentuje ujęcie tego zagadnienia od strony władz człowieka i powiązań między nimi, podkreślając tym samym, poznawczy i naturalny sposób, w jaki się dokonuje (w tym ujęciu jest oczywiście miejsce na perspektywę nadprzyrodzoną i kontemplowanie Boga - jedynie zaznaczona jest wyjściowa rola kontemplacji jako aktu intelektu i woli w odniesieniu do poznawanego bytu). Szyndler do analizy tekstów Akwinaty podchodzi z wypracowanymi już kategoriami określającymi to, na czym polega poznanie, czym jest rzeczywistość, a także to, czym jest filozofia w ujęciu Akwinaty. Z kolei Idźkowski, wychodząc od analizy tekstów Akwinaty, dostrzega niejednoznaczność wypowiedzi, następnie porządkuje terminologię, by uchwycić zasadnicze, zarazem całościowe i finalne, określenie kontemplacji. Okazuje się w jego ujęciu, że kontemplacja dotyczy bytów w taki sam sposób jak i Boga, że może dotyczyć naturalnej drogi poznawczej, ale może być także wydoskonalona przez całe nadprzyrodzone uposażenie człowieka ( $w$ ten sposób zapowiada wizję ostatecznej szczęśliwości, która polega na kontemplacji Boga). Spróbujmy krótko prześledzić najważniejsze punkty ich interpretacji tego zagadnienia.

Szyndler bardzo mocno podkreśla, że kontemplacja jest ściśle związana z obszarem rozumienia intelektualnego i przeciwstawia się działaniom, w których intelekt współdziała $\mathrm{z}$ innymi władzami poznawczymi czy dążeniowymi ${ }^{49}$. Jest

48 Zob. J. Idźkowski, Próba wyjaśnienia, czym jest kontemplacja według św. Tomasza z Akwinu, w: Człowiek i świat wokół niego. Studia z filozofii średniowiecznej, red. M. Manikowski, Wrocław 2008, s. 65-71.

49 Jego zdaniem oznacza to, że działanie intelektu możnościowego nastawione jest na pryncypia bytu, a nie na przypadłości bytu, poznawane przez zmysły zewnętrzne. W ten sposób kontemplacja jako zwrócenie się do bytu będzie oznaczała ostatecznie zwrócenie się do istnienia i jego własności przez wiązanie się z nim relacjami. Będzie to zwrócenie się do bytu jako gwaranta prawdy pojawiających się $\mathrm{w}$ intelekcie rozumień. Jednocześnie wyłączenie innych władz może być związane także ze wskazaniem, że inne władze mogą utrudniać działanie kontemplacji - za- 
zrozumiałe, że akt kontemplacji będzie bliższy rozumieniu (intelligere, simplex apprehensio) aniżeli rozumowaniu (ratiocinatio, discurrendo, inquisitio). Wyjątek, jeśli chodzi o współpracę z innymi władzami, stanowi wola, gdyż sama kontemplacja jest „zareagowaniem intelektu i woli na poznany byt (...) jest działaniem intelektu możnościowego wpływającego uzyskanym rozumieniem intelektualnym na wolę, intelektualną władzę dążeniową, w wyniku czego następuje skierowanie się do bytu (...) jest swoistym świadczeniem przez intelekt i wolę o realności bytu i łączących z nim więziach" 50 .

Kontemplacja jest działaniem (aktem) intelektu, a więc nie jest wiedzą (sprawnością), co więcej dokonuje się zanim intelekt zacznie wiedzę tworzyć. Oznacza to, że dokonuje się w ramach naturalnego poznania każdego człowieka, gdy intelekt osiągnie kres poznania i nastąpi zrodzenie słowa serca (verbum cordis). Według Szyndlera kres kontaktu poznawczego jest jednocześnie racją nabywania wszystkich usprawnień - zarówno teoretycznych (np. mądrość, wiedza), jak i praktycznych (np. synderezy). To, co szczególne w prezentacji Szyndlera, to akcent postawiony na zwracanie się człowieka w akcie kontemplacji do poznawanego bytu. $Z$ jednej strony jest więc zagwarantowana poznawanym bytem, a $z$ drugiej jest swoistym zwróceniem się do niego. Ten zwrot do bytu skutkuje po pierwsze skupieniem się na bycie (pewność poznania) a także zdumieniem wyrażającym się w nieznajomości przyczyn, które spowodowały poznawany przez nas skutek ${ }^{51}$. Jednocześnie Tomaszowe wypowiedzi o tym, że przedmiotem kontemplacji jest prawda $^{52}$, zyskują swoje uzasadnienie, gdyż intelekt: „dochodzi do zasady swego rozumienia. Stwierdza, choć nie w pojęciowy sposób, odpowiedniość, zgodność, ale i jednocześnie zależność między swoim «słowem serca» a bytem. Można po-

równo władze zmysłów wewnętrznych (szczególnie wyobraźnia), jak i zmysłowe władze dążeniowe (uczucia).

50 L. Szyndler, Zagadnienie „verbum cordis”, dz. cyt., s. 89-90; 94. Wpływ intelektu na wolę jest przez Szyndlera interesująco opisany. Jego zdaniem zgodnie z tekstami Tomasza można mówić o dwóch aspektach tego wpływu. Po pierwsze, intelekt swoim rozumieniem tak wpływa na wolę, że jest ona nastawiona, nakierowana na byt, realizuje postawę inclinatio (to wola staje się samą ,inklinacją” do dobra, które jest bytem). Po drugie, to nastawienie realizuje się za pomocą zamierzenia (intentio), które również dotyczy dobra jako celu działania. Zob. L. Szyndler, Zagadnienie „verbum cordis”, dz. cyt., s. 90-91

51 Zob. L. Szyndler, Zagadnienie „verbum cordis”, dz. cyt., s. 96. Zob. SENT II, d. 18, q. 1, a. 3, co. Zdaniem Szyndlera zdumienie obejmuje zarówno „samą rzeczywistość, jak również specyficzny sposób uzyskiwania takich ujęć przez człowieka”. Zob. L. Szyndler, Zagadnienie „verbum cordis”, dz. cyt., s. 98.

52 Zob. ST II-II, 180, a. 3, co. 
wiedzieć, że dopiero w tym momencie, gdy zostanie potwierdzona realność bytu, nastąpi swoisty powrót do niego, dokonuje się stwierdzenie zgodności ujęcia intelektualnego z samym bytem" ${ }^{53}$. W ten sposób stwierdzanie adekwatności w poznaniu, a więc i poznanie prawdy jest wynikiem aktu kontemplacji, przy czym przyczyną rozumienia jest byt, a intelekt wyłącznie stwierdzałby jego zgodność $\mathrm{z}$ bytem. Na sam koniec należy podkreślić za Szyndlerem, że według Tomasza delectatio jest swoistą „kropką nad i” działań poznawczych w ramach kontemplacji. Kontemplacja sprawia radość i zadowolenie, które, co ciekawe, stanowią znak rozpoznawczy zachodzenia jakiegokolwiek działania zgodnego z bytem i naturą danej władzy, jest to „sam akt danej władzy” ${ }^{54}$. W ten sposób to intelekt możnościowy odgrywa kluczową rolę w kontemplacji.

Idźkowski podkreśla z kolei, że w tekstach Tomasza bardzo trudno ustalić jednolitą i jednoznaczną koncepcję kontemplacji. Podkreśla on, że zasadnicze zręby wyjaśnienia kontemplacji można odnaleźć w relacji życia teoretycznego do praktycznego. Tomasz z Akwinu charakteryzując kontemplację odróżniał ją od innych aktów intelektu - szczególnie od aktu rozważania (cogitatio), badania (inquisitio) czy rozmyślania (meditatio). To, co charakterystyczne zdaniem Idźkowskiego w ujęciu Tomaszowym, to przedmiot, którym jest: 1) prawda, gdyż kontemplacja jest prostym jej ujęciem ${ }^{55}$; 2) Bóg, jako „Ostateczna Prawda i jedyna przyczyna rzeczywistości zmysłowo-umysłowo poznawalnej”56; 3) stworzenia ujęte w pierwszych zasadach, które jest rozważane w odniesieniu do Boga, gdyż prowadzi do Niego. Ten ostatni punkt zdaniem Idźkowskiego wynika $\mathrm{z}$ tego, że jeśli Bóg jest przedmiotem kontemplacji, to również stworzenia, przez które człowiek ogląda Boga, stanowią jej przedmiot. W tym aspekcie widzi on zwią-

53 L. Szyndler, Zagadnienie „verbum cordis”, dz. cyt., s. 96.

54 Tamże, s. 98.

55 Przez „simplex intuitus veritatis” Idźkowski rozumie intelektualny, intuicyjny ogląd rzeczywistości (podpadającej pod zmysły) w jej pierwszych zasadach bytowania, czyli pryncypiach, ale również wieńczący akt oglądu intelektualnego, czyli widzenie Boga. Zob. J. Idźkowski, Próba wyjaśnienia, czym jest kontemplacja, dz. cyt., s. 67.

56 J. Idźkowski, Próba wyjaśnienia, czym jest kontemplacja, dz. cyt., s. 67. Ten aspekt kontemplacji, w którym pojawia się Bóg, rozwija Izabella Andrzejuk w swoim artykule poświęconym relacjom pomiędzy omawianym aktem intelektu a mistycznym poznaniem per raptum. Interpretując również kontemplację u Tomasza, kładzie akcenty na jeszcze inne sprawy: odniesienie Tomasza do opisów kontemplacji w szkole Wiktorynów, wskazanie kontemplacji jako całościowego celu życia ludzkiego, samo „raptus” jest zinterpretowane jako właśnie kontemplacja. Zob. I. Andrzejuk, Kontemplacja i poznanie „per raptum”. Tomaszowe źródła rozumienia istoty doświadczenia mistycznego, „Rocznik Tomistyczny” 2017, nr 6, s. 59-76. 
zek między kontemplacją a „spekulacją”. W tym drugim działaniu odczytuje Tomaszowe videre per speculum, a więc widzenie w zwierciadle (odbiciu). O ile kontemplacja odnosiłaby się wprost do Boga, to przez spekulację mogłoby się dokonywać „widzenie Boga w stworzeniach lub poprzez stworzenia” ${ }^{2}$. W ten sposób „dostosowany do człowieka” sposób widzenia Boga oznaczałby korzystanie z władz zmysłowych, a także intelektu czynnego, który w aktach abstrahowania, rozumowania mógłby doprowadzić do poznawania Boga (oczywiście poznania tego, że istnieje). Tym samym rola intelektu czynnego nie tylko nie zostaje zbagatelizowana, ale wręcz pokazana jako konieczna w ramach działania kontemplacji.

Idźkowski bardzo mocno akcentuje za Tomaszem uwarunkowania zachodzenia kontemplacji, które dotyczą cnót moralnych i intelektualnych. Jak pisze: „cnoty porządkują nieuporządkowane poruszenia uczuciowe i tym samym odsuwają nastręczające się wyobrażenia, z drugiej zaś strony powstrzymują natłok zewnętrznych zajęć i chronią przed nadmiernym uwikłaniem się w sprawy «tego świata». Cnota moralna najistotniej oddziałująca przystosowawczo na czynność kontemplacji to umiarkowanie, gdyż to właśnie umiar odpowiada światłu i harmonii rozumu"58. Jego zdaniem według Tomasza teoretyczne sprawności intelektu mają zasadniczy wpływ na działanie kontemplacji, a szczególnie na jej jakość. Najważniejszą jest mądrość, obejmującą zarówno wiedzę, jak i sprawność rozumienia zasad. Usprawniona mądrość w człowieku powoduje pełniejszą kontemplację, „czyli tym głębsze i wyraźniejsze są ujęcia intelektu i tym większa łatwość ich wykonywania, oraz towarzysząca im przyjemność" ${ }^{59}$. W ujęciu Tomasza kontemplacja jest, zgodnie z Arystotelesowskim ujęciem, ściśle związana z ostatecznym szczęściem człowieka. Szczęście niedoskonałe, które może człowiekowi towarzyszyć w ramach filozoficznych dociekań jest tylko początkiem i zapowiedzią szczęścia doskonałego ${ }^{60}$. Tomasz zresztą, odwołując się do fragmentów biblijnych, interpretuje wypowiedź Chrystusa pochodzącą z Ewangelii św. Łuka-

57 Zob. ST II-II, 180 a. 3, ad 2; SENT III, d. 35, q. 1, a. 2, qc. 3, co. „Unde et nomen contemplationis significat illum actum principalem, quo quis Deum in seipso contemplatur; sed speculatio magis nominat illum actum quo quis divina in rebus creatis quasi in speculo inspicit".

58 J. Idźkowski, Próba wyjaśnienia, czym jest kontemplacja, dz. cyt., s. 69. Zob. ST II-II, q. 180, a. 2, ad 3; ST II-II, q. 182, a. 3, co.

59 J. Idźkowski, Próba wyjaśnienia, czym jest kontemplacja, dz. cyt., s. 69.

60 Zob. SENT III, d. 35 q. 1 a. 2 qc. 3 co. „Et similiter etiam felicitas contemplativa, de qua philosophi tractaverunt, in contemplatione Dei consistit: quia, secundum philosophum, consistit in actu altissimae potentiae quae in nobis est, scilicet intellectus, et in habitu nobilissimo, scilicet sapientia, et etiam objecto dignissimo, quod Deus est". 
$s z a$ a dotyczącą kontemplacyjnego życia i tego, że z dwóch kobiet tylko Maria wybrała „najlepszą cząstkę, której nie będzie pozbawiona” (Łk 10, 42). Tomasz pisze, powołując się na autorytet Augustyna: „Dowiedz się, dlaczego lepszą: bo jej nie będzie pozbawiona. Ty będziesz kiedyś pozbawiona ciężaru życia: wieczna jest słodycz prawdy"61. W ten sposób Tomasz zdecydowanie podkreśla wyższość życia kontemplacyjnego nad czynnym ${ }^{62}$. Idźkowski podkreśla ostatecznie, że akt kontemplacji według Tomasza jest ruchem okrężnym polegającym na konfrontacji i zestawianiu istnienia Boga i istnienia stworzeń, prostego pojmowania istnienia Boga i pojmowania istnienia Boga.

Jak zostało powiedziane, te dwie interpretacje są w pełni komplementarne. Teksty Tomasza pozwalają na szerokie zaprezentowanie tematu kontemplacji, a także na postawienie odpowiednich akcentów. Ujęcie kontemplacji od strony władz poznawczych, albo też zaakcentowanie doskonałego przedmiotu, do którego zmierza kontemplacja, są zgodne, choć różne. Warto jednak podkreślić, że Tomasz, pisząc o naturalnej kontemplacji, która faktycznie jest źródłem filozofowania, akcentował odwoływanie się do poznania zmysłowego, a także korzystania z intelektu czynnego. To dopiero kontemplacja teologiczna mogła „wyzwolić się" od abstrahowania (choć też nie do końca) i korzystać ze światła wiary, cnoty miłości oraz darów Ducha Św., które oddziaływały na intelekt i wolę człowieka. Tomasz, pisząc o naturalnej drodze kontemplacji, pisał jednoznacznie: „ludzka kontemplacja w obecnym stanie życia nie może obejść się bez wyobrażeń. Zdaniem Filozofa bowiem, zgodnie ze swoją naturą człowiek widzi umysłowe formy poznawcze $\mathrm{w}$ wyobrażeniach. Wszelako intelektualne poznanie nie zatrzymuje się na samych wyobrażeniach, ale w nich kontempluje czystość umysłowej prawdy. Zachodzi to nie tylko w poznaniu naturalnym, ale także w tym, co poznajemy $\mathrm{z}$ objawienia" ${ }^{63}$. Kontemplacja wychodzi, ale także rozwija się i dokonuje w ramach poznania, które polega na czerpaniu z wyobrażeń. I to $\mathrm{w}$ nich dokonuje się pojmowanie pryncypiów bytu. Nie oznacza więc to, że kontemplacja na wyobrażeniach się zatrzymuje.

${ }_{61}$ ST II-II, q. 182, a. 1, co. Cyt. za: Tomasz z Akwinu, Suma teologiczna. Charyzmaty, tłum. P. Bełch, t. 23, Londyn 1982, s. 167.

62 Tomasz uważa i tak, że kontemplacja ma znaczenie zarówno dla życia kontemplacyjnego, jak i czynnego. Zob. SENT III, d. 35, q. 1, a. 2, qc. 1, ad 1. „(...) finis contemplationis, inquantum contemplatio, est veritas tantum; sed secundum quod contemplatio accipit rationem vitae, sic induit rationem affectati et boni".

${ }^{63}$ ST II-II, q. 180, a. 5, ad 2. Cyt. za: Tomasz z Akwinu, Suma teologiczna. Charyzmaty, dz. cyt., s. 147. 


\section{Rola synderezy (prasumienia) i sumienia w etyce Akwinaty}

Przechodząc teraz do zagadnienia synderezy i sumienia, należy wspomnieć o historycznym kontekście pojawienia się tej problematyki. Ich odróżnienie pojawiło się na początku XIII w. u Aleksandra z Halles i zyskało popularność w całej myśli chrześcijańskiej. Syndereza oznaczała dla niego sumienie o ogólnym charakterze, które miało postać sprawności właśnie, natomiast sumienie miało szczegółowe zastosowanie i było aktem. Oczywiście, scholastyczni myśliciele wprowadzili wiele koncepcji sumienia nie tylko przypisując różne funkcje do tych określeń, ale także wiążąc nie tylko $\mathrm{z}$ intelektem możnościowym, lecz również $\mathrm{z}$ wolą (np. woluntaryzm Bonawentury, Henryka z Gandawy czy Ryszarda z Middleton). Samo greckie słowo „synderesis” zostało odczytane w jednym z komentarzy do księgi Ezechiela, które napisał św. Hieronim († 451). Greckie słowo pozostało $\mathrm{w}$ chrześcijańskich teoriach etycznych jako odpowiednik sprawności poprzedzającej jakikolwiek akt danej władzy (czy to poznawczy, czy pożądawczy), dla sumienia zaś zarezerwowano termin łaciński - „conscientia” ${ }^{64}$. Warto nadmienić, że dzięki pracom Stefana Swieżawskiego i jego tłumaczeniom tekstów Tomasza upowszechniło się stosowanie słowa „prasumienie” jako odpowiednika „synderesis".

Artur Andrzejuk za Tomaszem z Akwinu określił synderezę jako naturalną sprawność, co należałoby rozumieć jako sposób działania ludzkiego intelektu, wynikający z jego natury - jeśli podmiotuje on działania teoretyczne (sprawność pierwszych zasad), to również i działania praktyczne (sprawność synderezy) ${ }^{65}$. Tomasz nie waha się jej określić mianem sprawności wrodzonej, tłumacząc, że warunkiem jej zaistnienia jest akt poznawczy intelektu, w którym nastąpiłoby wydobycie i zaktualizowanie zasad postępowania ${ }^{66}$. Określenie prasumienia jako czegoś „naturalnego” oznacza to, że nie trzeba jej w szczególny sposób nabywać, że przysługuje każdemu bytowi rozumnemu jako takiemu. Jej wrodzoność w pewien sposób zostaje potwierdzona w Komentarzu do „Sentencji”: „intelekt

64 Zob. J. Zatorowski, Synderesis et conscientia. Koncepcja podmiotowej normy moralnej w tekstach Tomasza z Akwinu - jej źródła i kontynuacje, Warszawa 2013, s. 171-173. Por. A. Andrzejuk, Filozofia moralna w tekstach Tomasza $z$ Akwinu, Warszawa 1999, s. 50-53.

65 Zob. A. Andrzejuk, Prasumienie i sumienie w tekstach Tomasza z Akwinu, w: J. Zatorowski, Synderesis et conscientia. Koncepcja podmiotowej normy moralnej w tekstach Tomasza z Akwinu - jej źródła i kontynuacje, Warszawa 2013, s. 142-144.

66 Zob. QDV, q. 17, a. 1, ad 14. 
możnościowy sam z siebie jest niezdeterminowany, tak jak jest niezdeterminowana materia pierwsza, potrzebuje sprawności, dzięki czemu uczestniczyłby w słuszności swoich reguł"67. Funkcjonowanie według posiadanych reguł wyraża funkcjonowanie prasumienia. Wrodzoność nigdy nie zanika, przez co również nie zanika sprawność, która we władzach jest oznaką stałości - jak powie Tomasz: „dopóki trwa natura, nie można usunąć skłonności do dobra nawet u potępionych"68. Trwałość postępowania ludzkiego nie wynika z samej sprawności, ale jest oparta także na stałości samych zasad: „nie mogłoby bowiem być żadnej stałości ani pewności w tym, co wywodzi się z zasad, gdyby one same nie były mocno utwierdzone. Dlatego właśnie wszystko, co zmienne, sprowadza się do czegoś pierwszego niezmiennego. Dlatego również wszelkie poznanie pochodzi od jakiegoś najpewniejszego poznania, które nie może być błędne. Jest to poznanie pierwszych powszechnych zasad, które stanowią sprawdzian wszelkiego poznania i dzięki którym uznaje się wszelką prawdę i odrzuca wszelki fałsz"69. Tomasz, bardzo wyraźnie akcentując rolę synderezy, formułuje analogie do teoretycznego poznania pierwszych zasad. Jest tak dlatego, że chciał ją wpisać w ujęcie pięciu sprawności intelektu (czego nie dokonał Arystoteles mówiący o cnotach intelektu).

Skłonność do dobra i unikania zła, która jest wyrazem działania synderezy, jest podstawą wydawania sądów przez intelekt możnościowy. W dalszej kolejności są one podstawą określania przedmiotów naszych działań, a także podstawą ich oceny. Wedle Tomasza zasady ludzkiego działania (principia operabilia), wedle których działanie ludzkie wyznacza syndereza, pokrywają się z powszechnymi zasadami prawa naturalnego (universalia principia iuris naturalis) ${ }^{70}$. Zasady te, ze względu na umieszczenie ich w działaniach ludzkiego intelektu, będą w tym miejscu posiadały źródło porządku normatywnego.

Andrzejuk zwraca również uwagę, że Tomaszowa prezentacja synderezy podyktowana jest także odniesieniem jej do zdolności wolnego wyboru. Pisze on: „otóż syndereza wydaje sąd dotyczący powszechnych zasad postępowania (dobra i zła), natomiast do wolnego sądu należy orzekanie w konkretnych jednost-

67 SENT III, d. 23, q. 1, a. 1, co.: „Sed intellectus possibilis qui de se est indeterminatus, sicut materia prima, habitu indiget, quo participet rectitudinem suae regulae".

68 QDV q. 16, a. 3, ad 5. Cyt. za: Tomasz z Akwinu, De conscientia. O sumieniu, tłum. A. Białek, Lublin 2010, s. 41.

69 QDV q. 16, a. 2, co. Cyt. za: Tomasz z Akwinu, De conscientia. O sumieniu, dz. cyt., s. 34.

70 Zob. QDV q. 16, a. 1, co. 
kowych działaniach, co św. Tomasz nazywał także «sądem wyboru». Z nim św. Tomasz wiązał zagadnienie sumienia (conscientia), które stosuje powszechny sąd sumienia do szczegółowych działań i w tym zakresie może doznawać różnorakich braków i błędów"71.

Jeśli chodzi o sumienie, to jest ono „aktem zastosowania którejkolwiek sprawności lub wiedzy do jakiegoś jednostkowego działania"72. Sumienie jest doradcą, świadkiem i sędzią naszego postępowania ${ }^{73}$, przez co staje się główna zasadą moralności. Tomasz oczywiście rozkłada tę odpowiedzialność zarówno na sprawność, jak i właśnie akt, uwypuklając to, że sam akt stale zależy od sprawności, którą właśnie w literaturze polskiej określa się „prasumieniem”. Aplikowanie wiedzy w akcie sumienia oznacza dla Tomasza skorzystanie ze sprawności wiedzy oraz roztropności jako sprawności intelektu możnościowego, a także z poznania, które dokonuje się w zmysłach zewnętrznych aktualnie bądź dokonywało się uprzednio (przez co korzystamy z pamięci jako jednego ze zmysłów wewnętrznych $)^{74}$. Skorzystanie ze sprawności wiedzy może się dokonać albo poprzez nakazanie tego, co należy czynić, bądź też nie czynić, albo po dokonaniu czynu, poprzez ocenę tego, „czy czyn był prawy, czy też nie”75. Tomasz wskazuje, że te dwie drogi są analogiczne do funkcjonowania wiedzy teoretycznej - w ramach odkrywania i sądzenia (via inveniendi et iudicandi). W Kwestiach dyskutowanych o prawdzie pisze: „Gdy bowiem na podstawie wiedzy namyślamy się, co wypada uczynić, jakby naradzając się sami z sobą, przypomina to odkrywanie, polegające na wyprowadzaniu wniosków z zasad. Gdy zaś rozważamy i badamy, czy to, co już zostało uczynione, jest prawe, przypomina to drogę sądzenia, polegającą na sprowadzaniu wniosków do zasad"76. Skutkiem tych dwóch rodzajów aplikacji wiedzy są odpowiednie akty sumienia: 1) pobudzanie, nakłanianie

71 A. Andrzejuk, Syndereza i sumienie w tekstach św. Tomasza z Akwinu, w: Tomasz z Akwinu, De conscientia. O sumieniu, tłum. A. Białek, Lublin 2010 s. 118. QDV, q. 17, a. 1, co. Cyt. za: Tomasz z Akwinu, De conscientia. O sumieniu, dz. cyt., s. 52. Zob. A. Andrzejuk, Prasumienie i sumienie w tekstach Tomasza z Akwinu, dz. cyt., s. 153.

74 W tym miejscu warto wspomnieć o współczesnych debatach prowadzonych przez tomistów nad zagadnieniami etycznymi, które wiążą się ściśle z neuronaukami. Temat fundowania zachowań etycznych na podstawie zmysłów wewnętrznych podejmuje M. Mróz w artykule: Physiological and Psychological Foundation of Virtues: Thomas Aquinas and Modern Challenges of Neurobio$\log y$, „Scientia et Fides” 2018, No. 2, s. 115-128. Dyskusje nad zagadnieniami neuranuk podejmuje również P. Lichacz: Neuroetyka a Tomasz z Akwinu. O użyteczności myśli średniowiecznej we wspótczesnych debatach etycznych, Warszawa 2018.

$75 Q D V$, q. 17, a. 1, co.

76 QDV, q. 17, a. 1, co. Cyt. za: Tomasz z Akwinu, De conscientia. O sumieniu, dz. cyt., s. 54-55. 
i zobowiązanie, gdy sumienie skłania nas do czynu; 2) oskarżanie i dręczenie, gdy akt jest niezgodny $\mathrm{z}$ wiedzą; 3) obrona lub uniewinnienie, gdy działanie jest wedle sumienia adekwatne do wiedzy ${ }^{77}$.

Akwinata, dotykając zagadnienia sądu sumienia, podkreśla różnice, jakie zachodzą między nim a wolnym wyborem i sądem wyboru (iudicium electionis). O ile syndereza odnosiła się do ogólnych zasad działania, o tyle obydwa wymienione sądy dotyczą konkretnego działania. Sąd sumienia ma mimo wszystko charakter poznawczy, w przeciwieństwie do sądu wyboru, który właśnie jest zastosowaniem poznania do aktów woli (affectiones). Ta dystynkcja i niesiony wraz $\mathrm{z}$ nią problem etyczny sprowadza się do niezwykle intrygującego zagadnienia, które wyjaśnia Andrzejuk: „na mocy sądu wolnego wyboru człowiek podejmuje działania, co do których posiada negatywny sąd sumienia. Przyczyną tego stanu rzeczy są okoliczności towarzyszące samemu działaniu, np. krępujący wolę strach lub przeciwnie - pożądliwość"78.

Tomaszowa koncepcja sumienia uchodzi za intelektualistyczną, ale jednocześnie za rygorystyczną. Akwinata jest bowiem przekonany, że sumienie obowiązuje w sposób bezwzględny, nawet gdyby można było jego ocenę uznać za błędną. Taka ocena zresztą wskazywałaby bardziej na samą błędną wiedzę, aniżeli na słabość woli, czy też samego sumienia. Tomasz w Summie teologii rozwiązuje problem obowiązywalności błędnego sumienia, odróżniając rodzaje czynów, które (1) są z natury dobre, (2) obojętne, lub też (3) z natury złe. Tomasz odrzuca jako niesłuszny pogląd, wedle którego sumienie nie powinno obowiązywać, gdyby nakazywało rzeczy, które są same w sobie złe, lub też zabraniało rzeczy, które są same w sobie dobre. Wedle niego nawet w takich sytuacjach wolę (intelektualne pożądanie) należałoby ocenić negatywnie (jako złą), nie mówiąc o sytuacji, w której mielibyśmy do czynienia z czynem obojętnym moralnie (Tomaszowy przykład: powstrzymanie się od rozwiązłości, które może być przedstawione przez wiedzę człowieka jako zło, uczyni wolę złą) ${ }^{79}$. Tomasz rozważa także drugą stronę tego pytania: czy błędne sumienie usprawiedliwia $\mathrm{z}$ błędnych działań podjętych $\mathrm{z}$ tego powodu? Przy tym pytaniu wskazuje jednoznacznie, że problem tkwi w samej wiedzy: ,jeżeli błąd rozumu lub sumienia jest błędem, który popełnia się dobrowolnie - bądź przez bezpośrednie chcenie, bądź przez

\footnotetext{
77 Zob. QDV, q. 17, a. 1, co.

78 A. Andrzejuk, Prasumienie i sumienie w tekstach Tomasza $z$ Akwinu, dz. cyt., s. 156.

79 ST I-II, q. 19, a. 5.
} 
zaniedbanie, jak to jest z błędem dotyczącym tego, co ktoś powinien wiedzieć wówczas tego rodzaju błąd nie uwalnia od winy i nie zmienia niczego w tym, że wola zgodna $\mathrm{z}$ rozumem lub sumieniem popełniającym taki błąd jest zła" ${ }^{80}$. Tak więc należy podkreślić dobitnie, że błędne sumienie, które jak się wydaje powinno usprawiedliwiać z powodu błędnej wiedzy (np. nie zawinionej), nie usprawiedliwia w żaden sposób i nadal obowiązuje.

\section{Podsumowanie}

Mądrość, kontemplacja oraz syndereza i sumienie wyraźnie pokazują, w jaki sposób poznawcze działania intelektu możnościowego i czynnego służą rozpoznaniu rzeczywistości, a w dalszej konsekwencji pozwalają na działania wynikające z natury ludzkiej, rozpoznającej siebie i dobro, do którego ma zmierzać. Uwagi na temat intelektu możnościowego i czynnego jako odpowiadających za działania moralne człowieka uzasadniaja przypisywany Tomaszowi intelektualizm etyczny, gdyż to właśnie władze poznawcze warunkują jakiekolwiek akty dążeniowe i wybory. Mądrość, kontemplacja i syndereza wraz z sumieniem uzasadniają wyodrębnienie tych zasad jako odpowiadających swoistej „etyce intelektu”, która nie będąc całą etyką Tomaszową, akcentuje funkcje intelektualne służące rozpoznaniu bytu, a w dalszej kolejności rozpoznaniu prawdy i dobra. To, że Akwinacie przypisuje się etykietę intelektualisty etycznego, może wydawać się oczywiste, jednak wyjaśnienie, jaki jest sens tej etykiety powinno być przedmiotem szerszych badań. Ukazanie intelektualnych działań poznawczych może stanowić jedynie wstęp do szerszego uzasadnienia takiego przypisywanego Tomaszowi stanowiska.

Mądrość jest sprawnością intelektu możnościowego wiążącą się ze sprawnościami różnych rodzajów wiedzy, a także sprawnością rozumienia zasad. Mądrość jest wiedzą o rozpoznanej rzeczywistości w jej ostatecznych przyczynach, a także wiedzą o ostatecznej przyczynie. W praktycznym wymiarze mądrość wiąże się z porządkowaniem, poznaniem prawdy, smakowaniem płynącym z wiedzy, a także zasadą życia ludzkiego. Kontemplacja jest aktem intelektu możnościowego, który posługuje się działaniem intelektu czynnego w rozpoznawaniu rze-

80 ST I-II, q. 19, a. 6. Cyt. za: Tomasz z Akwinu, Traktat o ludzkim działaniu, tłum. W. Galewicz, Kęty 2013, s. 209. 
czywistości zmysłowej tak, aby dostrzeżone było w niej to, co konieczne i ogólne (abstrakcja). Kontemplacja rzeczywistości wiąże się z jej rozpoznawaniem i zatrzymywaniem tak, aby istniejące byty stanowiły punkt odniesienia jakiegokolwiek dalszego aktu poznawczego, a także aktu wyboru. Syndereza jest praktyczną sprawnością intelektu możnościowego, sumienie zaś aktem tegoż intelektu. Syndereza, będąc sprawnością, odpowiada za realizację „złotej reguły” postępowania moralnego, natomiast sumienie korzysta z niej w ocenie każdorazowego pragnienia i podjętej decyzji.

\section{Bibliografia}

Andrzejuk A., Filozofia moralna w tekstach Tomasza z Akwinu, Warszawa 1999. Andrzejuk A., Prasumienie i sumienie w tekstach Tomasza z Akwinu, w: J. Zatorowski, Synderesis et conscientia. Koncepcja podmiotowej normy moralnej w tekstach Tomasza z Akwinu - jej źródła i kontynuacje, Warszawa 2013, s. 131-169.

Andrzejuk A., Syndereza i sumienie w tekstach św. Tomasza $z$ Akwinu, w: Tomasz z Akwinu, De conscientia. O sumieniu, tłum. A. Białek, Lublin 2010, s. 111-128.

Andrzejuk I., Kontemplacja i poznanie «per raptum». Tomaszowe źródła rozumienia istoty doświadczenia mistycznego, „Rocznik Tomistyczny” 2017, nr 6, s. 59-76.

Arystoteles, Metafizyka, tłum. K. Leśniak, Warszawa 2009.

Gogacz M., Ku etyce chronienia osób. Wokół podstaw etyki, Warszawa 1991.

Gogacz M., Mądrość buduje państwo, Niepokalanów 1993.

Gogacz M., Sumienie, kontemplacja, mądrość ( $z$ problematyki podstaw etyki), „Studia Philosophiae Christianae” 1989, nr 25, z. 2, s. 65-71.

Gogacz M., Wprowadzenie do etyki chronienia osób, Warszawa 1998.

Hoffmann T., The intellectual virtues, w: The Oxford Handbook to Aquinas, red. B. Davies, E. Stump, Oxford 2012, s. 327-336.

Idźkowski J., Próba wyjaśnienia, czym jest kontemplacja wedtug św. Tomasza $z$ Akwinu, w: Człowiek i świat wokół niego. Studia z filozofi średniowiecznej, red. M. Manikowski, Wrocław 2008, s. 65-71. 
Lichacz P., Neuroetyka a Tomasz z Akwinu. O użyteczności myśli średniowiecznej we współczesnych debatach etycznych, Warszawa 2018.

Mróz M., Physiological and Psychological Foundation of Virtues: Thomas Aquinas and Modern Challenges of Neurobiology, „Scientia et Fides” 2018, No. 2, 115-128.

Przanowski M., Święty Tomasz z Akwinu o Bogu. Studia teologiczne, Warszawa 2015.

Szyndler L., Zagadnienie „verbum cordis” w ujęciu Tomasza $z$ Akwinu, w: Wokót średniowiecznej filozofii języka, red. A. Górniak, t. 1, Warszawa 2002, s. 21115.

Tomasz z Akwinu, O cnotach rozumu. Komentarz do VI księgi „Etyki nikomachejskiej” Arystotelesa, tłum. M. Głowala, J. Kostaś, M. Otlewska, W. Ziółkowski, Wrocław 2010.

Tomasz z Akwinu, Suma teologiczna. Charyzmaty, tłum. P. Bełch, t. 23, Londyn 1982.

Tomasz z Akwinu, Suma teologiczna. O Trójcy przenajświętszej, tłum. P. Bełch, t. 3, Londyn 1978.

Tomasz z Akwinu, Suma teologiczna. Umiarkowanie, tłum. S. Bełch, t. 22, Londyn 1963.

Tomasz z Akwinu, Traktat o cnotach, tłum. W. Galewicz, Kęty 2006.

Tomasz z Akwinu, Traktat o ludzkim działaniu, tłum. W. Galewicz, Kęty 2013.

Tomasz z Akwinu, Traktat o roztropności, tłum. W. Galewicz, Kęty 2011.

Zatorowski J., Synderesis et conscientia. Koncepcja podmiotowej normy moralnej w tekstach Tomasza z Akwinu - jej źródła i kontynuacje, Warszawa 2013.

Zembrzuski M., Sprawności intelektu wyrazem wewnętrznej kultury osoby w kontekście myśli Tomasza z Akwinu, „Studia Philosophica Wratislaviensia” 2016, t. 11, nr 3, s. 85-102.

Zembrzuski M., Wychowanie jako uprawa intelektu. Problematyka sprawności intelektu w ujęciu wybranych tomistów polskich (J. Woroniecki, S. Swieżawski, M. Gogacz), Myśl pedagogiczna neoscholastyki i neotomizmu, red. A. Murzyn, M. Krasnodębski, Warszawa 2014, s. 179-202. 


\section{Streszczenie}

Celem artykułu było zaprezentowanie czterech zasad etyki Tomasza z Akwinu. Mądrość, kontemplacja, a także syndereza i sumienie można określić zarówno jako sprawności, ale także akty intelektu możnościowego. Pokazują one w sposób wystarczający w jaki sposób poznawcze zdolności intelektu służą do poznania rzeczywistości a także wynikają $\mathrm{z}$ natury ludzkiej rozpoznającej siebie a także dobro, które jest jej celem. Lektura tekstów Tomasza z Akwinu na temat mądrości, kontemplacji oraz synderezy i sumienia pozwala dostrzec jak wielką rolę odgrywają $\mathrm{w}$ postępowaniu moralnym oraz jak usprawiedliwiają Tomaszowy intelektualizm etyczny. To właśnie te działania intelektu determinują każdy akt woli i każdy wybór człowieka.

Słowa kluczowe: mądrość, kontemplacja, syndereza, sumienie, etyka, Tomasz z Akwinu, cnoty i sprawności, intelekt możnościowy i czynny

\section{Summary}

\section{Wisdom, contemplation, synderesis and conscience in the ethics of Thomas Aquinas}

The aim of the article was to present four principles of the ethics of Thomas Aquinas. Wisdom, contemplation, synderesis and conscience are either habits and acts of the possible intellect. Wisdom, contemplation and synderesis and conscience clearly show how the cognitive activities of the intellect serve to recognize reality, and, in a further consequence, allow actions resulting from human nature that recognize self and the good to which it is to aim. Remarks about wisdom, contemplation as well as synderesis and conscience, as responsible for moral actions of man, justify ethical intellectualism attributed to Aquinas, because the intellect determines any volitional acts and choices.

Key words: wisdom, contemplation, synderesis, conscience, ethics, Thomas Aquinas, virtues and habits, possible and agent intellect 